\title{
ЈЕДАН ТИП РУСКИХ СУФИКСОИДАЛНИХ СЛОЖЕНИЦА У ТЕРМИНОЛОШКОЈ ФУНКЦИЈИ И ФИХОВО ТРАНСПОНОВАЬЕ НА СРПСКОХРВАТСКИ ЈЕЗИК
}

У савременом руском језику веома је присутна тенденција стварања аналошких сложеница у области терминолошке лексике. Ради се о афиксоидалним сложеницама ${ }^{1}$ код којих се, по одређеном моделу, понављају делови сложенице. Овом приликом реч је о једној врло продуктивној групи агентивних именских сложеница са општим значењем лица, које путем суфиксације дају значење врсте делатности. Конкретно, ради се о суфиксоидалним сложеницама код којих, по терминологији В. В. Виноградова, суфигирани део чини морфема - вод: ${ }^{2}$ птицевод, скотовод, гусевод, овцевод; кукурузовод, хлопковод, бахчевод, коноплевод итд. Далеко највећи део ових сложеница мотивисан је префиксалним глаголом разводить са значењем гајити, узгајати, одгајати (билке и животиғе). Актуелни глагол разводить у овом значењу представља замену за ранији глагол водить који је имао и ово значење. Другу, малобројну групу

1 Н. М. Шанский, Афбиксоиды в словообразовательной системе современного русского титературного языка. У зборнику: Исследования по современному русскому языку. Сборник статей, посвященных памяти проф. Е. М. ГалкинойФедорук. Издательство Московоского университета, Москва 1970, стр. 251-257; Е. А. Васильевская, Словосложение в русском языке. Учпедгиз, Москва 1962, стр. 96-98.

2 Русская грамматика. І. АН СССР, Издательство „Наука”, Москва 1980, стр. 248 и 251; И. Ф. Протченко, Лексика и словообразование советской эпохи. АН СССР, Институт русского языка. Издательство „Наука”, Москва 1975, стр. 163-164; Способы номинации в современном русском языке. АН СССР, Институт русского языка. Издательство „Наука”, Москва 1982, стр. 261-262; Л. А. Шкатова, Различные степени терминологизации наименования лии. У зборнику: Современные проблемы русской терминологии. АН СССР, Институт русского языка. Издательство „Наука”, Москва, 1986, стр. 37-52. 
сложеница са морфемом -вод чине сложенице са значењем прибора за померање нечег: волновод, пульповод, водовод; пищевод, яйцевод. Трећу, такође малобројну, групу чине сложенице с овом морфемом у значењу лица које се бави неком делатношћу или њоме руководи: счетовод, деловод, групповод, руковод, зкскурсовод, кукловод, плотовод, верховод.

Сложенице прве и делимично треће групе могу да послуже као творбена база за суфиксацију помоћу суфикса -ство, за означавање врсте делатности: садоводство, овощеводство, бахчеводство, овиеводство, свиноводство; счетоводство, домоводство, деловодство. Другим деривационим могућностима агентивних сложеница са морфемом -вод овом приликом нећемо се бавити.

Агентивне сложенице са компонентом -вод и изведенице са -cmво морају се разматрати у својој комплементарности, зато што се ради о односу деривације и редеривације са хронолошком димензијом. Наиме, семантички посматрано, код једних сложеница овога типа најпре је настао назив за вршиоца радње у гајењу и узгајању животиња и биљака, а тек онда је изведен назив за ту врсту делатности помоћу суфикса -ство. Код других сложеница поступак је био обрнут. У корпусу који је послужио као основица за ово истраживање од преко осамдесет јединица, сакупљених из разних извора (речници - општи и терминолошки, каталози, стручни текстови) највише је корелативних парова по хронолошком моделу хмелевод - хмелеводство. Има, међутим, случајева када један члан тога пара у овом материјалу изостаје: картофелевод - * картофелеводство. Занимљиво је да чешће изостаје вршилац радње: забележени су примери гусеводство, индейководство, ословодство, льносеменоводство, осетроводство, а изостају ${ }^{\star}$ гусевод, *индейковод, *ословод, ${ }^{\star}$ льносеменовод, ${ }^{*}$ осетровод итд. То, свакако, не значи да се у ужим круговима узгајивача ти термини не употребљавају, али, бар засад, речници те лексеме не региструју. Неки парови се постепено попуњавају другим корелатом, што показују тзв. „развојни” речници (Новые слова и значения ${ }^{4}$ - декад-

${ }^{3}$ Грамматика русского языка. І. АН СССР. Институт русского языка. Издательство АН СССР, Москва 1960, стр. 272; Образование употребительных слов русского языка. Под редакцией Л. С. Засориной. Изд. „Русский язык”, Москва 1979, стр. 146.

${ }^{4}$ Новые слова и значения. Словарь-справочник по материалам прессы и титературы 60-х годов. АН СССР, Институт русского языка. Изд. „Советская энциклопедия", Москва 1971; Новые слова и значения. Словарь-спровочник по материалам прессы и литературы 70-х годов. АН СССР, Институт русского языка. Изд. „Русский язык”, Москва 1984. 
ни речници за шездесете и седамдесете године, као и годишњаци Новое в русской тексике).

Заслужује у вези с овим пажњу и једна семантичко-терминолошка корелативност која се односи на суфиксоидалне сложенице с морфемом - вед ${ }^{5}$ за означавање научне и стручне области и морфемом -вод за означавање узгајања биљних и животињских врста. Нису ретки наслови стручних публикација, уџбеника и приручника типа Лесоведение и лесоводство, што би описно значило „науку о шумама” и „узгајање и коришћење шума”. Оба та руска термина покрива наш термин жумарство, о чему сведочи Матичин Речник. Овде, свакако, настаје и један преводилачки проблем: да ли двочлани руски наслов „покрити” нашим економичним термином жумарство или пак тај наслов превести описно. Ако се пак та два руска термина употребљавају у одвојеним контекстима, наш термин жумарство може испасти непрецизан све дотле док се на неки посредан начин не установи да ли је реч о науци о шумама или о узгајању и коришћењу шума.

Постоје две основне семантичке класификације суфиксоидалних сложеница прве групе са морфемом -вод, тј. оних које су везане за појмове „узгајивач” или „узгајање”. Код прве класификације узимају се у обзир речи с општијим значењем (скотовод - скотоводство, птицевод - птицеводство; растениеводство и сл.) и речи с конкретним значењем везаним за одређену животињу или биљку (овцевод - овцеводство, свиновод - свиноводство; кукурузовод - кукурузоводство, табаковод - табаководство). ${ }^{6}$ Друга класификација односи се на посебно разматрање флоре (тутовод - тутоводство, лесовод - лесоводство) и фауне (скотовод - скотоводство, фазановод - базановодство). ${ }^{7}$

Стварање терминолошке лексике ове врсте у руском језику свакако је отворен процес, што се може констатовати увидом у поменуте „развојне” речнике. Једна од последњих речи из ове сфере на коју смо наишли у једној научнопопуларној публикацији је женьшеневодство (узгајање женшена, гинсенга). По тој логици претпостављамо да постоје и термини норковод - норководство, везани за гајње визона, нерчева, јер такве

5 Б. Терзић, О питану номенклатуре наука и струка са становишта двојезичности. У зборнику: Настава страног језика као језика струке у средюем, вишем и високом образовану. Друштво за примењену лингвистику Србије, Чачак 1988, стр. 44-51.

${ }^{6}$ Э. А. Григорян, Приниипы классификации суфбиксоидов (на материале сложных существительных с корнями глаголов движения в опорном компоненmе). Филологические науки, Москва 1981, 3, стр. 55.

7 Э. А. Григорян, нав. дело, стр. 55-56. 
фарме постоје и имају велики привредни значај, али ову појаву речници још не региструју.

У другој групи сложеница на -вод, тј. оних које означавају прибор за померање нечег, издвајају се две семантичке групе:

а) механизми за пренос: воздуховод, волновод, бетоновод, световод;

б) делови људског и животињског организма: яйцевод, пищевод. ${ }^{8}$

Трећа група је семантички монолитна (групповод, экскурсовод и сл.). Јасно је да су сложенице друге и треће групе у погледу морфеме -вод мотивисане глаголом водить у његовом основном значењу. ${ }^{9}$

Типолошки посматрано руски језик је у погледу суфиксоидалних сложеница са -вод, уосталом као и у погледу суфиксоидалних сложеница са -вед, структурно монолитнији у односу на српскохрватски језик. То се нарочито односи на сложенице са семантиком „гајити, узгајати”. Већ из овог што је досад речено дају се наслутити транспозициона решења терминолошког реда, везаног за појмове „узгајивач” - „узгајање”. Еквивалентност се овде постиже помоћу суфиксације и синтагматским путем.

\section{I. Суфиксација}

Основни српскохрватски суфиксацијски еквиваленат представљају изведенице са суфиксом -ар за лице и -арство за грану, област. У овом случају ретки су други суфикси (бахчевод - бостанција). Еквиваленти се дају на основу постојећих речника српскохрватског језика, као и на основу постојећих двојезичних руско-српскохрватских и српскохрватско-руских речника, ${ }^{10}$ у источној и западној варијанти српскохрватског језика.

а) Флора: хмелевод - хмељар, узгајивач, произвођач хмеља // хмеловодство - хмељарство; иветовод - цвећар (узгајивач и продавац) // изветоводство - цвећарство; луговод - ливадар // луговодство - ливадарство; коноплевод - конопљар // конопле-

${ }^{8}$ Э. А. Григорян, Словообразовательные форманты „-вод”, „-водеи”, „-провод”, „-отвод”, в современном русском литературном языке. Русский язык в школе, 1981, 4, стр. 79-80.

9 Э. А. Григорян, нав. дело под 8, стр. 80.

$10 \mathrm{y}$ време писања овога рада још није био изашао из штампе $P y$ ско-српскохрватски речник у редакцији Богољуба Станковића (Нови Сад - Матица српска, Москва - „Русский язык”, 1988), те материјал из њега овде није заступљен. 
водство - конопљарство; семеновод - сјеменар, одгајивач сортног сјемења // семеноводство - сјеменарство; овощевод - повртлар // овощеводство - повртларство; садовод - вртлар, вртар; плодовод - воћар; плодоовощевод - воћар и повртлар // плодоовощеводство - воћарство и повртларство.

б) Фауна: пчеловод - пчелар // пчеловодство - пчеларство; птииевод - перадар, живинар // птищеводство - перадарство, живинарство; животновод и скотовод - сточар; животноводство и скотоводство - сточарство; шелковод - свилар, одгајивач свилених буба; голубевод - голубар; козоводство - козарство, гајење коза.

У вези с овом врстом еквиваленције треба истаћи два проблема. Прво, наше изведенице са суфиксом -ар могу имати и друга значења ван значења „одгајивач, узгајивач”: извећар - а) узгајивач, произвођач цвећа; б) продавац цвећа; в) љубитељ цвећа; свилар - а) узгајивач свилених буба; б) трговац свилом. ${ }^{11}$ Пошто се у терминолошкој лексици тежи ка једнозначности, ова хомонимија може понекад да буде препрека усвајању основног терминолошког значења. У том случају би целисходно било применити синтагматски начин транспозиције.

Друго, не постоји увек семантичка корелативност, између изведеница на -ар и -арство у оквиру значења о којем је овде реч. На пример, руском корелативном пару овцевод - овцеводство формално био би еквивалентан наш пар овчар - овчарство. Међутим, овчарство одговара руском овцеводство, али овчар не одговара руском овцевод, јер, према речницима нашег језика, овчар значи чувар оваца, а не и узгајивач оваца. Исто је и са речју - свиғар.

\section{II. Синтагматски начин}

Синтагматска транспозиција се остварује по моделу „одгајивач, узгајивач”, понекад „произвођач” + генитив (чешће множине) именице садржане у првом делу руске сложенице.

a) Флора: чаевод - узгајивач чаја // чаеводство - узгајање чаја; $m a-$ баковод - узгајивач духана, одгајивач дувана // табаководство - узгајање духана, одгајање, гајење дувана; хлопковод - узгајивач памука // хлопководство - гајење памука; льновод - одгајивач, произвођач лана // льноводство - узгајање, гајење, произ-

11 Речник српскохрватскога књижевног језика. Матица српска, Нови Сад, књига пета 1973, књига шеста 1976. 
водња лана; рисовод - узгајивач риже, пиринча // рисоводство - узгајање риже; иитрусовод - узгајивач агрума̂ // uиттрусоводство - узгајање агрума̂; тутовод - узгајивач дуда // mутоводство - узгајање дуда; картофелевод - узгајивач кромпира // картофелеводство - узгајање кромпира; каучуковод - узгајивач каучуковца // каучуководство - узгајање каучуковца.

б) Фауна: рыбовод - узгајивач рибе // рыбоводство - узгајање, производња рибе; червовод (червевод) - узгајивач дудова свилца // червоводство (червеводство) - узгајање дудова свилца; козовод - одгајивач коза (не козар - рус. козиц̆ пастух) // козоводство - гајење коза; собаковод - узгајивач паса // собаководство - узгајање паса; зверовод - узгајивач животиња са скупоценим крзном // звероводство - узгајање животиња са скупоценим крзном; устрицевод - узгајивач острига // устрицеводство узгајање острига.

Синтагматски начин транспоновања нарочито долази до изражаја када је у питању флора и фауна које нема у нашем поднебљу: соболевод - узгајивач самура̂ // соболеводство - узгајање самура; каракулевод - узгајивач астраханских оваца // каракулеводство - узгајање астраханских оваца; оленевод - узгајивач северних јелена, ирваса, собова // оленеводство - узгајање северних јелена, ирваса, собова; зебувод - одгајивач зебуа (грбавих бикова) // зебуводство - узгајање зебуа; сайгаковод - узгајивач сајгака (врста антилопе) // сайгаководство - узгајање сајгака; мараловод - узгајивач марала (сибирских јелена) // мараловодство - узгајање марала и сл.

Двојезични речници дају често оба еквивалента - и суфиксални и синтагматски, нарочито тамо где би сам суфиксални начин услед већ поменуте хомонимије могао изазвати недоумице: лесовод - шумар, узгајивач шуме; шумарски стручњак; иветовод - цвјећар, узгајивач цвјећа (већ смо видели да цвећар може имати три значења); шелковод - свилар, одгајивач свилених буба; кроликовод - кунићар, узгајивач кунића; семеновод - сјеменар; одгајивач сортног сјемења.

Кад је реч о нашим двојезичним руско-српскохрватским речницима, треба рећи да они често не региструју сложенице овога типа, које би се лако могле транспоновати на наш језик помоћу једног од два поменута начина: свекловод - узгајивач (произвођач) цвекле; кукурузовод узгајивач (произвођач) кукуруза; ословод - узгајивач магараца; фазановод - одгајивач фазана; осетровод - узгајивач јесетре. 
У неколико случајева транспозиција се може остварити по моделу „стручњак + за + акузатив именице за ознаку области”: парниковод стручњак за стакленично вртларство (повртарство, баштованство); сортовод - стручњак за биљне врсте; растениевод - стручњак за гајење биља, за културу биља.

Код творбеног пара коневод и коновод ради се о разлици у творбеној мотивацији: сложеница коневод мотивисана је глаголом разводить (гајити, узгајати) и значи коюогојаи, узгајивач коюа, док је сложеница коновод мотивисана глаголом водить (водити), и значи коюоводаи.

У неколико случајева еквиваленти за врсту делатности (-водство) изводе се помоћу другог дела који гласи -гојство: рыьбоводство - рибогојство (Матичин Речник); коневодство - коњогојство и коњарство; свиноводство - свињогојство и свињарство.

Сложенице друге групе (прибор за померање нечег) транспонују се углавном синтагматски: волновод - спроводник таласа; воздуховод спроводник ваздуха; световод - спроводник светлости и сл. Једино су сложенице везане за анатомију монолексемне: пищевод - једњак; яйевод - јајовод. Ова врста руских сложеница не служи као творбена база за суфикс-ство.

Сложенице треће групе (лице које се бави неком врстом делатности или њоме руководи) различито се транспонују:

а) монолексемно: счетовод - рачуновођа; деловод - деловођа; плотовод - скелеџија;

б) полилексемно: групповод - вођа групе; экскурсовод - вођа екскурзије одн. водич; кукловод - аниматор лутака и сл. Само понека од ових руских сложеница може да послужи као творбена база за суфикс -ство, чиме се означава врста делатности: счетоводство - рачуноводство.

Као што се из претходне анализе види, међујезички контакти у овој области дериватологије пружају могућности и за сагледавање неких ширих типолошких својстава руског и српскохрватског језика. 
Богдан Терзич

ОДИН ТИП РУССКИХ КОМПОЗИТ С СУФИГИРОВАННЫМ ВТОРЫМ КОМПОНЕНТОМ В ТЕРМИНОЛОГИЧЕСКОЙ ФУНКЦИИ И СПОСОБЫ ИХ ТРАНСПОНИРОВАНИЯ НА СЕРБОХОРВАТСКИЙ ЯЗЫК

Резюме

Автор анализирует продуктивную категорию русских композит со вторым компонентом -вод (ство), показывает как они функционируют в современном русском языке и исследует способы их транспонирования на сербохорватский язык. Сербохорватскими эквивалентами являются производные существительные с суффиксом -ар (ство) и словосочетания, созданные по модели „одгајивач, узгајивач + родительный падеж существительного из первого компонента композит". В структурно-типологическом отношении русский язык в данном случае более монолитен, чем сербохорватский язык. 